DOI:

\title{
Struggling to maintain diversity: The marginalisation of Playcentre in government early childhood education and care policy
}

\author{
Suzanne Manning \\ University of Auckland
}

Playcentre is a parent cooperative early childhood service where parents are trained and supported as the educators in the service. Once considered a 'mainstream' service, policy has increasingly marginalised Playcentres in favour of supporting teacher-led services. This article gives a background of parent cooperative services, and then reviews policies of the fifth National government from 2008, with an emphasis on how these policies have accommodated or excluded Playcentre. This review is presented as an argument for maintaining diversity in the early childhood education and care sector by developing policy which accommodates parent cooperative services.

Keywords: Early childhood education and care, ECE policy, Playcentre

\section{Playcentres and policy}

Parent cooperative early childhood education and care (ECEC) ${ }^{1}$ services, such as Playcentres, are an established part of the ECEC sector in Aotearoa New Zealand. At the time of the education reforms in 1989, Playcentres were considered a major service type within the ECEC sector. Since that time, government policy has increasingly marginalised Playcentres and other parent cooperative services through an emphasis on developing a teacher-led sector. Although there is a body of literature which analyses the changing ECEC policy over the last three decades, ${ }^{2}$ much of it has paid minimal attention to Playcentres. This article explores the specific impacts of selected ECEC policies on Playcentres in the last decade, particularly those that were based on the distinction of teachers or parents as the educators in the service. The strategic plan for early childhood education (SPECE; Ministry of Education, 2002) introduced the terminology of teacher-led and parent-led services to categorise this distinction. In this paper the term parent cooperative is used in preference to parent-led services as a resistance to the binary created through the SPECE terminology.

The first section of this article outlines the historical context of the division between parent cooperatives and teacher-led services in ECEC policy, leading up to the 2011 Early Childhood Education (ECE) Taskforce report (ECE Taskforce, 2011). Three selected policy work streams are then examined from a Playcentre perspective. The policies considered are the review of the decile funding system for schools and ECEC services (e.g., Ministry of Education, 2016a), the updating of the ECEC curriculum Te Whāriki (Ministry of Education, 2017a), and

\footnotetext{
${ }^{1}$ ECEC is my preferred term for such services, as it emphasises that 'care' is included with education.

${ }^{2}$ For example, see the writings of academics Sue Cherrington, Carmen Dalli, Sarah Farquhar, Helen May, Linda Mitchell, Anne Smith and Sarah Te One.
} 
support for professional learning, research and innovation in ECEC (Ministry of Education, 2016b; Teaching and Learning Research Initiative, n.d.). The final section will consider how ECEC policy might be able to move beyond a teacher-led/parent cooperative binary to accommodate different service philosophies.

\section{Historical context of parent cooperative ECEC services}

The diversity of ECEC services in Aotearoa New Zealand can be categorised in many ways. They can be categorised by whether or not they operate out of a centre (which can be purpose-built or shared with other groups), the number of hours they are open, the dominant language used, the specific philosophy underpinning the service, licence status, ownership (community based, private, or corporate), or whether the educators are also the parents of the children attending. Government support has tended to prioritise certain categories of ECEC services over others. From the 1940s to 1980s, the government priority was support for part-day services only. The rationale was to assist but not replace the mother as the primary carer of children (May, 2009).

The Before Five ECEC reforms of the late 1980s (Department of Education, 1988) introduced a universal administration system designed to treat all ECEC equally. Distinguishing between part-day and full-day services was no longer important, while other categories arose. These included whether or not a parent was present with an under-twoyear-old child for funding purposes (Department of Education, 1989), and had different qualification and supervision requirements for services that had high parent involvement (Ministry of Education, 1990). This division between services employing teachers and nonparental staff members, and those services that used parents-as-educators ${ }^{3}$ was reified in the language of SPECE a little over a decade later (Ministry of Education, 2002). Developing a teacher-led ECEC sector was an explicit goal of government policy from this time. The overall effect for Playcentres was a marginalisation in policy, because of the philosophy and practice of parents-as-educators.

Parent cooperative ECEC services have a long history in Aotearoa New Zealand. The first major parent cooperatives were Playcentres, which started during the 1940s. In the 1950s and 60 s they were the second most popular ECEC service after Kindergartens (May, 2009). Playcentres developed systems of group supervision, where parents were involved in running the half-day sessions. The frequency of this involvement varied as each Playcentre could choose its own style of supervision. This was either full group supervision, with all parents staying for every session their child attended, team supervision where parents were rostered onto a team one (or two) sessions per week and could leave their children at other times, or supervised sessions where a supervisor was employed and parents were rostered on to help once every two to three weeks (Manning, Woodhams, \& Howsan, 2011). To support this involvement, Playcentre also developed a supervisor training programme (Stover, 1998).

The other major ECEC parent cooperative service was Ngā Kōhanga Reo. These Māoriimmersion services were developed from the 1980s by Māori, for Māori, with the kaupapa (purpose) of revitalising te reo me ōna tikanga (language and culture) of the Māori people. Ngā Kōhanga Reo, similar to Playcentres, operated as autonomous but affiliated centres that operated with differing styles of supervision but always welcomed whānau and family

\footnotetext{
3 I use the term "parent-as-educators" to refer to Playcentre parents being the educators at the ECEC centre, and to differentiate this from education for parents, which might be the role of a "parent educator".
} 
member involvement. The Kōhanga Reo Trust also developed a training programme for their educators (Waitangi Tribunal, 2012).

The policy categories of services with high parent involvement and 'others' (i.e., teacher-led services) were originally created to accommodate the practice of parents-aseducators with regards to qualifications requirements. In 1989 when the Before Five minimum standards for ECEC services were developed, it was proposed that all services would be required to have a single person responsible for the service, and that person would need to hold a three-year Diploma of Teaching ${ }^{4}$. This was to ensure that at least one person had advanced training in ECEC as a step towards upskilling all staff. The New Zealand Playcentre Federation (NZPF) objected both to the 'single person' and diploma requirements as being against the Playcentre philosophy of group supervision and parents-as-educators. ${ }^{5}$ The political compromise, contained in the qualifications blueprint (Ministry of Education, 1990), was to establish two sets of qualifications criteria: one for services with high parent involvement, and one for services without such involvement. The NZPF at the time considered that this was a validation of Playcentre philosophy (Playcentre Journal Editor, 1990).

The fifth Labour-led government appointed a working party in 2000 to develop a 10year strategic plan (Ministry of Education, 2002). The SPECE working group was cognisant of the need to accommodate parent cooperatives, with Anne Meade as Chairperson promoting in her opening speech the value of the different groups "walking and talking together" 6 to develop the strategic plan. The final SPECE presented two groups of strategies based on the two categories of the qualifications blueprint. Thus, the terminology of 'teacher-led' and 'parent-led' services entered into ECEC discourse. However, the strategies for parent cooperatives were less defined and less numerous than those for teacher-led services, so in reality little changed in terms of policy and regulation for parent cooperative services.

This categorisation was used in the 2004 budget announcement to exclude parent cooperatives from the 20 Hours ECE funding. The funding was designed to compensate teacher-led services for the increased regulatory costs arising from the SPECE. ${ }^{7}$ The funding review for parent cooperatives, promised in the SPECE, never eventuated. ${ }^{8}$

The fifth National-led government, elected in 2008, appointed the ECE Taskforce in 2010 to review the sector, and its report was released in 2011 (ECE Taskforce, 2011). The Taskforce used the divisions of teacher-led/parent-led and centre-based/home-based to recommend the exclusion of parent cooperatives and home-based care from mainstream ECEC funding and policy. There was a public outcry in support of Playcentres, Ngā Kōhanga Reo and home-based care services, to the extent that the government announced that the funding to these services would not be cut (Minister of Education, 2011). There was some further work done on the Taskforce policy suggestions (Ministry of Education, 2012), but the major funding classification and reorganisation were never implemented.

\footnotetext{
${ }^{4}$ Ministry of Education. (1989). Early childhood education qualifications, Accreditation and Training Working Group. National Archives, Wellington R7250452.

${ }^{5}$ New Zealand Playcentre Federation. (1989-1990). Subject files: Before Five folder. Alexander Turnbull Library, Wellington, 97-030-10.

${ }^{6}$ Anne Meade's opening speech to the SPECE working party, as reported in the minutes of the first meeting on 31 August 2000. Alexander Turnbull Library, MS-Papers-10827-13

7 May, H. (2003-2004). Early childhood education government funding papers (i), Alexander Turnbull Library, Wellington, MS-Papers-10796-51.

${ }^{8}$ Meade, A. (2011, January 30). Submission to ECE Taskforce, Hocken Collections, Dunedin, r7628 6/9.
} 
The fact that the Taskforce felt justified in making the recommendation to exclude parent-led and home-based care services from mainstream funding indicates the shift in thinking over the two decades since the 1988 Before Five reforms. Such a recommendation would not have been politically acceptable at the time of either Before Five or the SPECE working groups. The change in thinking can be attributed in part to an increasing emphasis on human capital as a rationale for government ECEC support (Stuart, 2016). This rationale is essentially an economic one, where the purpose of ECEC services is seen as ensuring that children are getting the desired foundation in academic skills for later schooling success, future productivity and contribution to the economy. Such a purpose necessitates careful control and standardisation of the quality of ECEC services by the government. The human capital development of parents is an important secondary rationale, as government support for ECEC services enables parents to contribute to the economy through paid employment. The human capital development rationales co-exist with rationales based on children's rights, but the human capital emphasis in policy has been growing in dominance in the new millennium (Haggerty \& Alcock, 2016; Manning, 2018; Stuart, 2016).

Parent cooperatives do not fit well with human capital objectives as there is inherent variability among the parents-as-educators because of the reliance on field training rather than pre-service training, the inclusion of all parents regardless of education or ability, and the requirement for parental time commitment (Manning, in press; Manning et al., 2011). However, Playcentres are good at developing communities of learners, which can benefit parents and children alike (Podmore \& Te One, 2008; Powell, Cullen, Adams, Duncan, \& Marshall, 2005; van Wijk \& Wilton Playcentre members, 2007). The aims of Playcentres therefore differ in some ways from the government's desired outcomes of ECEC (Manning, 2018).

Policy development since the Taskforce report in 2011 has continued to be predominantly based on human capital theory (Stuart, 2016). This has meant that despite policy changes, overall Playcentres and other parent cooperatives have remained on the margins of the sector. To illustrate this marginalisation, three policy work streams from 2011 to 2017 will be analysed for the way the policies accommodate Playcentre philosophy and practice. The analysis will highlight the problems that are represented in the policies, as these problem representations shape the way that policy is formed and which solutions are chosen (Bacchi, 2009). According to Carol Bacchi, we are governed by these problem representations, and therefore to change the overall direction of policy the problem representations and their effects must be made visible.

\section{Funding reviews}

In 2010, the National-led government dropped the SPECE target from employing $100 \%$ qualified teachers in teacher-led ECEC services to $80 \%$, and this was followed by cutting the funding band for 80-100\% qualified teachers (May, 2014; Smith \& May, 2018). This affected kindergartens in particular (Wannan \& Livingston, 2015), but also those childcare centres eligible for Rate 2 quality funding. With this policy change, the government departed from the discourse of 'quality equals qualifications'. The message was that the baseline for quality was a mix of qualified teachers and unqualified or in-training staff, and that was the mix that the government was prepared to fund. 
The ECE Taskforce in 2011 recommended a modified approach, arguing for the benefits of a fully qualified ECEC workforce. However, the funding system proposed was based not on the proportions of qualified teachers but on the attributes of the individual children attending the service. A higher rate was proposed for services classified as high quality services, which would necessitate some sort of rating system. The proportion of qualified teachers would no longer be used as a proxy for quality:

Proposed system: Rate differentiation is an incentive to providers (teacher quality incentive not related to cost).

Rationale: We want to encourage services to improve quality, but we do not believe that meeting the full cost of additional teachers is the best way of doing that. Teacher pay should be determined between a teacher and their employer. Wealthier parents should be prepared to meet some of the cost of early childhood education, which includes some of the cost of a higher-quality workforce.

Existing features: Rate differentiation meets cost (e.g. cost of teachers).

(ECE Taskforce, 2011, p. 77)

This proposal was a move away from the cost driver approach of the 20 Hours policy, which was based on the principle that the government would fully fund the cost of providing twenty hours ECEC. The proposal was that $80 \%$ qualified teachers in any one centre was adequate for minimal quality, and additional teachers/quality should be funded by the parents as well as by an incentive subsidy from the government. This appeared to suggest a system where wealthy parents would pay for a higher-quality ECEC workforce and less wealthy parents would only have access to a lower-quality ECEC workforce. The Taskforce did not represent this as a problem.

In contrast, Playcentres, with trained parents being the educators on session, were problematic for the Taskforce. The Taskforce proposal was that funding should be targeted to high quality services, defined as teacher-led and centre-based services. Parent cooperatives and home-based services were to be minimally funded. The problem was represented as needing to increase the quality of services through supporting teachers, which disqualified parent cooperatives and home-based services from being included in the policy recommendation. The emphasis on teacher-led services as the only route to quality ECEC was related to the Government's human capital objectives. Investment in ECEC as human capital development required certainty and control, which could be provided by teachers but not by parents-as-educators (Manning, 2018, in press).

Although the government did not implement the Taskforce's recommendations for a change in the ECEC funding system, a further review of funding was started in 2015, encompassing both school and ECEC funding. A cabinet paper in 2016 presented the problem with the current system:

Current funding systems for early learning and schooling have developed in ad hoc ways over time and focus on the inputs for running an entity rather than the educational outcomes for children and young people. Less obvious - but just as worrisome in an increasing competitive global market - is the lack of lift and stretch in student learning potential. We see the measure of this in the declining numbers of New Zealand students in the top percentile of international benchmarks. These benchmarks also show a decline in performance by New Zealand students, both compared to other countries and against our previous results. (Ministry of Education, 2016a, p. 4) 
This problem representation illustrates the underlying assumptions of human capital theory. The goal of education was presented as achieving academic qualifications in order to improve the country's future competitiveness in the global market. The solution proposed was more targeted funding, based on individual children and not on the institutional entity providing the service. The proposed change was therefore very similar to that of the Taskforce. The Taskforce had proposed in 2011:

Payments would no longer be based on licensed numbers. The amount of subsidy would be calculated and paid through a formula-based funding mechanism that recognises the needs of individual children. We describe this as the per-child-hour subsidy, to be paid for a specified number of hours participation per week. (p. 72)

Echoing this proposal in November 2016, the Cabinet paper recommended:

3.1 a core funding model in both early learning services and state integrated schools made up of two components:

3.1.1 a curriculum-based per-child funding amount - as the funding basis and tailored to the learning expectations of children and young people at each stage of the curricula. In early learning this involves moving to per-child funding.

3.1.2 additional funding for individual challenges. (Ministry of Education, 2016a, p. 1)

Unlike the Taskforce, the Minister of Education committed to keeping the diversity of the ECEC sector and was not intending to differentiate between funding for 'teacher-led, centrebased' and 'other' services:

No change is envisaged to the funding differentials between different types of early learning services, such as between kindergartens and home-based services. (Ministry of Education, 2016a, p. 12)

This funding proposal was approved, and more detailed policy work was underway when the Labour coalition government was elected in 2017.

A key feature of the per-child funding was that funding would no longer be attached to specific components of 'quality' as had been the focus since the mid-1990s when Rate 2 quality funding was introduced. This new proposal assigned money on the perceived educational challenge of the children, and the ECEC provider would be expected to meet those challenges in whatever way they chose. Initiatives for achieving quality provision, which would be an expected feature of ECEC services, were decoupled from funding. The funding based on the child also avoided the issue of reinstating the funding band for $80-100 \%$ teachers.

The funding review was subsequently discontinued (Minister of Education, 2018). It is difficult to know how these proposals would have affected Playcentres if they had been implemented. Since they were based on the numbers of children attending a centre, small Playcentres, which form the majority of ECEC services in the rural locations (Mitchell, Royal Tangaere, Mara, \& Wylie, 2006), would have been adversely affected through an inability to generate sufficient income. This would have been offset by the proposed supplementary funding for small and isolated services. Quality incentives in these proposals were separate from the funding rates, and this could possibly have been beneficial for Playcentres that might have had the freedom to define what 'quality' was in their own centres rather than meet standardised criteria designed with teacher-led services in mind. 


\section{Updating Te Whāriki}

A second major policy work stream during the 2010s was the ECEC curriculum update. The ECE Taskforce in 2011 addressed one of its policy essays and four recommendations towards reviewing the implementation of the 1996 ECEC curriculum, Te Whāriki (Ministry of Education, 1996). This was justified in economic terms:

A holistic, socioculturally-based curriculum is a key component of quality early childhood education provision. ... Te Whāriki is considered a model of best practice, nationally and internationally, but could benefit from a comprehensive review of its implementation. We recommend that this takes place as soon as possible. ... A robust review could identify cost-effective ways to improve outcomes from early childhood education in New Zealand. (Early Childhood Education Taskforce, 2011, p. 106)

Three years later the Ministry of Education set up the Advisory Group on Early Learning (AGEL), to address the variable implementation of Te Whāriki:

There is, however, wide variation in how well Te Whāriki is implemented by early childhood education (ECE) services and how the foundation it provides is carried on into the early years of schooling. (AGEL, 2015, p. 39)

Over the years since its introduction, Te Whäriki had become a crucial part of quality standards, and therefore variability in its implementation was represented as a problem to be solved. This was pointed out by the Taskforce in 2011 (Early Childhood Education Taskforce, 2011), the Organisation for Economic Cooperation and Development's Aotearoa NZ country profile in 2012 (OECD, 2012), and the Education Review Office in 2013 (Education Review Office, 2013), as well as the AGEL report in 2015. The AGEL report made 20 overlapping recommendations, which were all deemed high priority. The group considered that these recommendations "together ... comprise an inter-related strategy for strengthening implementation of Te Whāriki and supporting continuity of learning across the early years" (Advisory Group on Early Learning, 2015, p. 8).

While none of the recommendations directly addressed the issue of qualifications in ECEC, the AGEL supported a return to $100 \%$ qualified teachers as a baseline for effective implementation of Te Whāriki:

These demands suggest that formal qualifications are essential. The Advisory Group debated whether all early education and care services teachers should be qualified to the equivalent of a bachelor's degree. We acknowledge the continuing professional and industrial campaigns here and overseas aimed at lifting the workforce's qualifications, and the uneven qualifications base still in effect here. All teachers of five- to eight-yearolds must have a degree, but the same does not apply to all teachers of children from birth to four. The group therefore supports, as a professional principle, moves towards a fully qualified early childhood education and care workforce in Aotearoa New Zealand. (Advisory Group on Early Learning, 2015, p. 8)

The report did not give an opinion on how Playcentre parents-as-educators would fit into the fully qualified workforce. The language of most of the report and the recommendations simply used the terminology of provisional and qualified teachers. 
The Ministry accepted the AGEL's recommendation to commission an update of Te Whāriki and in 2016 set up a group of "early learning academics and practitioners to develop a draft of Te Whāriki for wider consultation" (Ministry of Education, 2017b, p. 2). The writing group also consulted with the writers of the original Te Whäriki. A consultation draft was released in November 2016, with these major changes from the 1996 version:

1. updated context, language, examples, and implementation advice

2. stronger bicultural framing and a focus on identity, language, and culture, and on inclusion of all children

3. fewer, clearer learning outcomes

4. links to The New Zealand Curriculum and Te Marautanga o Aotearoa

5. a streamlined structure that is more easily navigated

6. The overarching structure of principles, strands, and goals was unchanged. (Ministry of Education, 2017b, p. 2)

The following consultation showed widespread sector support for the changes, and a number of concerns. For the NZPF the biggest concern was the absence of acknowledgement of different philosophies and approaches to ECEC, in particular the practice of parents-aseducators. The clear separation between parents and teachers, a discursive effect of the quality policies, continued to frame the thinking about adults in ECEC (Manning, in press). Some of the consultation feedback referred to the theoretical underpinning of the new draft Te Whāriki marginalising ECEC services with different philosophies, including parent cooperatives:

In general, these respondents thought the theories of learning and development section did not reflect the breadth of theories that underpin the various philosophies in ECE. ... Some approaches that were seen to be marginalised were Steiner, Montessori, hospital or home-based education, and whānau and parent-led services.

Reasons behind this included:

1. limited reference to all philosophies and service settings

2. some learning outcomes that contained concepts incompatible with some learning philosophies

3. no description of what constitutes a kaiako. (Ministry of Education, 2017b, p. 11)

This quote refers to the debate around the use of the word 'kaiako' throughout the document. Words from a different language often do not translate directly, but bring with them cultural connotations. While this Māori word means 'teacher', its use signalled a willingness to consider a wider range of meanings associated with the term. Since the term was being used in a wider context than previously, the sector wanted an explicit and agreed definition. Feedback through the consultation debated possible meanings and uses:

The term kaiako, which the draft used as an umbrella term for a range of roles associated with the care and education of children in ECE settings, received a considerable amount of feedback.

Overall there was mixed support for the term's use. Some strong views were expressed, especially by those who did not support it. Many felt its use conflated non-qualified and qualified teachers. Another concern was the reduction in status that qualified ECE teachers could face if they were referred to differently from their primary and secondary 
peers. There was concern about how kaiako responsibilities tied in with the Education Council's teacher competencies. In general, respondents noted there could be conflicts from trying to set out generic responsibilities that encompass a diverse group of people.

Respondents representing parents and play centres were not against use of the term. But they frequently stated that the definition did not clearly refer to parents, and this needed to be amended. Others observed that the term could be used more consistently throughout the draft, for instance, where the word "adult" had been used, "kaiako" would be more appropriate. (Ministry of Education, 2017b, p. 13)

The debate shows the tensions that the writers faced between supporting the principle of a fully qualified ECEC workforce and accommodating the philosophies of parent cooperative services. The NZPF negotiated with the writers to make sure that a reference to parents-aseducators was included in a definition of 'kaiako' (S. Bailey, Co-President of the NZPF, personal communication, 30 June 2017). The final version of Te Whāriki had this footnote definition of the term:

Kaiako includes all teachers, educators and other adults, including parents in parent-led services, who have a responsibility for the care and education of children in an ECE setting. In settings where parents have collective responsibility for the curriculum, it is understood that kaiako will also be parents and whānau. Although ECE services use a range of different terms, this document uses kaiako because it conveys the reciprocal nature of teaching and learning, which is valued in this curriculum. (Ministry of Education, 2017a, p. 7)

The NZPF saw this as successful advocacy for the inclusion of Playcentre philosophy and practice (Bailey, personal communication, 30 June 2017). However, it also shows the increasing move towards standardisation and consequent reduction of diversity in the ECEC sector; now parent cooperatives were only accommodated as an after-thought.

\section{Professional learning and development and research partnerships}

The third policy work stream concerns government support for ongoing professional development and research in the ECEC sector. The government has funded professional learning and development (PLD) contracts since the mid-1990s, originally to assist ECEC services to implement the new early childhood curriculum, Te Whāriki (Cherrington, 2017; Ministry of Education, 1996). Providers of PLD were set up, often attached to university Faculties of Education. The NZPF was awarded a contract to provide PLD specifically to Playcentres (Stover, 2001), and has continued to hold such contracts with the Ministry since that time. Although individual Playcentres could choose to work with any PLD provider, most preferred to work with the NZPF PLD team, as confirmed by an evaluation of PLD programmes in 2013:

Services with particular characters or philosophies value highly undertaking PD with providers who have in-depth and first-hand knowledge of the service types they are working with. In addition to Immersion Māori and Pasifika services discussed above, playcentre and home-based services clearly prefer working with providers and facilitators who have this expertise and can tailor programmes to fit their philosophy. (Cherrington et al., 2013, p. 7) 
Successive governments have changed the parameters for the PLD contracts, including what the focus topic can be, whether centres choose PLD or are directed to participate because of a poor Education Review Office report, and the size of the funding. During the term of the fifth National government, the funding was cut and the restrictions became tighter, in line with the government's general philosophy of targeting funding to areas of most need and generating the best return on investment (Cherrington, 2017). The NZPF PLD team managed to cope with the changing parameters, despite the difficulties that this sometimes caused. ${ }^{9}$

The PLD contracts constituted a successful example of government policy accommodating the Playcentre approach to ECEC. Funding was provided independent of the service operating model, with the NZPF gaining contracts as a provider of PLD. This enabled Playcentres to access Playcentre-specific PLD, which was beneficial for supporting Playcentres (Cherrington et al., 2013; Cherrington \& Wansbrough, 2007; Mitchell et al., 2006), and did not come at the expense of other services' access to PLD. If the Taskforce recommendations to restrict PLD support to only teacher-led centre-based services had been implemented, Playcentres would have been denied access.

However, Playcentres were denied access to a recent initiative to support research in ECEC. There have been several initiatives since the 2000s for supporting, developing, and sharing good practice between ECEC services, where researchers and practitioners have been paired together (Smith \& May, 2018). The first was a SPECE strategy to "establish six Centres of Innovation on a three-year cycle to showcase excellence and innovation in ECE" (Ministry of Education, 2002, p. 15). The first six Centres of Innovation (COIs) were selected from applicants in 2003, and there were two more rounds of selection in the following years. The objectives for the COIs were to:

- build the use of innovative approaches that result in improved early childhood learning and teaching based on Te Whāriki: Early Childhood Curriculum;

- facilitate action research, with the help of researchers, to show the results the innovative approaches have on learning and teaching;

- share the knowledge, understanding and models of practice with others in the early childhood education sector and parents/whānau. (Podmore \& Te One, 2008, p. 1)

All ECEC services were eligible in principle to apply to be selected as a COI. Two Playcentres were selected: Wilton Playcentre in 2003 (van Wijk et al., 2006), and Te Marua Mangaroa Playcentre in 2005 (Podmore \& Te One, 2008). These projects showed the capability of teams of parents working in centres as educators to produce useful and professional research, in conjunction with professional researchers. When the COI programme was set up, there was no suggestion that Playcentres would not be eligible.

The Labour Government also set up a programme in 2003 called the Teaching and Learning Research Initiative (TLRI), administered by the New Zealand Council for Educational Research. The TLRI sought to "enhance the links between educational research and teaching practices to improve outcomes for learners" (Teaching and Learning Research Initiative, n.d., Home page). The definition of 'teacher' for the TLRI programme was defined broadly enough to include the Playcentre approach:

\footnotetext{
${ }^{9}$ Author's personal experience with the NZPF PLD team \& L. Neill, NZPF PLD Facilitator, personal communication, 13 July 2017.
} 
To be eligible for the fund, proposals need to come from partnerships involving teachers and researchers. In the context of the TLRI, teachers are defined as education and training practitioners. (Teaching and Learning Research Initiative, n.d. Apply for funding page)

The Canterbury Playcentre Association was successful in their application for a funding grant in 2008, and carried out a two-year project with their research partners on supporting children's working theories (Davis \& Peters, 2011).

The fifth National government from 2008 did not take the same view of parent cooperatives' ability to contribute to the ECEC sector through research. The government stopped the COI programme in 2008, although the TLRI programme, which was aimed at both the school and ECEC sectors, continued (Smith \& May, 2018). The Taskforce in 2011 recommended that the government establish "a new, high-quality early childhood education innovation scheme" (ECE Taskforce, 2011, p. 162). Despite the Taskforce rhetoric that "overall policy settings for early childhood education need to harness the skills, expertise and enthusiasm of all members of this diverse sector to improve early childhood education quality" (ECE Taskforce, 2011, pp. 79-80), parent cooperative services were not included in this diversity. Hidden in a different section of the report, the Taskforce also recommended that services that were not centre-based and teacher-led should not be eligible for the Service grants, which included "innovation grants, awarded competitively" (ECE Taskforce, 2011, pp. 79-80).

Although the National Government did not fully accept the Taskforce's recommendations, the 'innovation scheme' was one recommendation that did have extra policy development. In 2015 the government set up the Teacher-Led Innovation Fund for the schooling sector:

The purpose of the Teacher-led Innovation Fund is to provide funding for groups of teachers to develop innovative practice in order to improve learning outcomes, particularly for Māori students, Pasifika students, those with special education needs and those from low socio-economic backgrounds. (Ministry of Education, 2016b, p. 3)

The scheme contained the principles of National's social investment educational policy approach; that is, targeting specific populations deemed 'at risk' of educational failure and an emphasis on measurable learning outcomes (Boston \& Gill, 2017). The TLIF was extended to the ECEC sector in 2017, in preference to setting up a separate ECEC scheme (Ministry of Education, 2016b). The issue for Playcentre was that the TLIF scheme eligibility was limited to "certified ECE teachers and kaiako in kōhanga reo holding Tohu Whakapakari" (Ministry of Education, 2016b, p. 2), which excluded teams of parents-as-educators working in Playcentres. This exclusion was confirmed by the Ministry of Education in response to my request for clarification (TLIF, personal communication, July 19, 2017). Whether the exclusion of Playcentres from the TLIF was deliberate, or whether it was a side-effect of an administratively simple policy solution, it is difficult to say. However, it does illustrate that where it is taken for granted that quality is equated with qualifications and with teachers, Playcentres will be excluded. 


\section{Policy for parent cooperative services}

Playcentres as parent cooperative services have a long history of contribution to the early childhood sector, and to society in general through their parent support and development. However, the government rationale for supporting ECEC has increasingly become focused on achieving human capital development outcomes, focused on future economic productivity for children and current economic productivity for parents. This requires standardised goals across the sector, and a standardised approach to providing a quality service. Policy based on these rationales promotes a teacher-led sector, and a fully qualified workforce. Such policy disadvantages Playcentres, which have a different approach to quality outcomes for young children by using parents-as-educators. Playcentres also have a different end goal in mind, which is community building and the holistic support of parents, focused on the role of parents as parents rather than workers.

Policy since 2011 has had mixed impacts for Playcentres, but continues to contribute to the marginalisation of parent cooperative services because of the emphasis on a distinct separation between the role of teacher and parent. This separation is blurred in a Playcentre setting, and the NZPF has to work to get policy makers to accommodate this approach. The reviews of funding from 2008 to 2017 promoted a model based on differential funding for the educational challenge of the children to replace the mixed model currently that allocates the same funding to all children, but has different funding rates for different services. Among other things, such a model would remove the Rate 2 quality funding based on proportions of qualified teachers. This has the potential to benefit Playcentres as there might be potential to define quality in a different way. However, whenever the funding is predominantly based on numbers of children attending, the small and rural Playcentres are disadvantaged. The small centre top-up, introduced in 2004, would need to be continued in some form to support these centres which operate in areas of low population density.

The debate around the naming of ECEC kaiako has implications in policy. The updated Te Whāriki included a definition of kaiako which includes Playcentre parents-as-educators, after advocacy from the NZPF. The process of accommodating Playcentre philosophy and practice highlights the tensions that exist between promoting a fully qualified ECEC workforce and promoting the value of diversity across the sector. Some schemes for workforce development in ECEC such as the Teaching and Learning Research Initiative have found ways to balance this tension and include Playcentres, and others like the Teacher-Led Research Initiative exclude Playcentres because of the language and definitions used. If the ECEC sector in Aotearoa New Zealand is to maintain the diversity of services that has often been considered a strength of the sector, then policy needs to actively include the different approaches, philosophies and practices of diverse services. This issue should be considered in the early learning strategic plan being developed in 2018, which will be informing the government's ECEC policy work in the future. ${ }^{10}$ Playcentre has an opportunity to be reaffirmed as a realistic and supportive option for parents who wish to take on active roles as educators of their children, and to be acknowledged for its role in building communities.

10 Ministry of Education, Early learning strategic plan, https://conversation.education.govt.nz/conversations/early-learning-strategic-plan/ 


\section{References}

Advisory Group on Early Learning. (2015). Advisory Group on Early Learning report to the Ministry of Education. Retrieved from https://www.education.govt.nz/assets/Documents/Ministry/consultations/ Report-of-the-Advisory-Group-on-Early-Learning.pdf

Bacchi, C. (2009). Analysing policy: What's the problem represented to be? Frenchs Forest, Australia: Pearson.

Boston, J., \& Gill, D. (Eds.). (2017). Social investment: A New Zealand policy experiment. Wellington, NZ: Bridget Williams.

Cherrington, S. (2017). Professional learning and development in early childhood education: A shifting landscape of policies and practice. The New Zealand Annual Review of Education, 22, 53-65. doi:10.26686/nzaroe.v22i0.4148

Cherrington, S., Shuker, M. J., Stephenson, A., Glasgow, A., Rameka, L., \& Thornton, K. (2013). Evaluation of the Ministry of Education-funded early childhood education professional development programmes. Retrieved from https://www.educationcounts.govt.nz/ publications/ECE/Evaluation_of_MoE_Funded_ECE_PD_Programmes

Cherrington, S., \& Wansbrough, D. (2007). An evaluation of Ministry of Education funded early childhood education professional development programmes. Wellington, NZ: Ministry of Education.

Davis, K., \& Peters, S. (2011). Moments of wonder, everyday events: Children's working theories in action. Retrieved from http://www.tlri.org.nz/tlri-research/researchcompleted/ece-sector/moments-wonder-everyday-events-children\%E2\%80\%99sworking

Department of Education. (1988). Before five: Early childhood care and education in New Zealand. Wellington, NZ: Government Printer.

Department of Education. (1989). Before five newsletter. Education Gazette, 68(16), supplement.

Early Childhood Education Taskforce. (2011). An agenda for amazing children. Retrieved from http://www.taskforce.ece.govt.nz/

Education Review Office. (2013). Working with Te Whāriki: Education evaluation reports. Retrieved from http://www.ero.govt.nz/publications/working-with-te-whariki/

Haggerty, M., \& Alcock, S. (2016). The changing roles of early childhood care and education in Aotearoa New Zealand: A shifting policy landscape. Global Studies of Childhood, 6(1), 136-146. doi:10.1177/2043610615625164.

Manning, S. (2018). Blocks are educational: Revealing discourses through early childhood policy illustrations. History of Education 47(2), 241-256. doi:10.1080/0046760X.2017.1420245.

Manning, S. (in press). The Early Childhood Education Taskforce and Playcentre parent cooperatives: A mismatch of policy discourses. International Journal of Child Care and Education Policy.

Manning, S., Woodhams, M., \& Howsan, S. (2011). Emergent leadership in Playcentre. Journal of Educational Leadership, Policy and Practice, 26(2), 3-13.

May, H. (2009). Politics in the playground: The world of early childhood in New Zealand (Rev. ed.). Dunedin, NZ: Otago University Press. 
May, H. (2014). New Zealand: A narrative of shifting policy directions for early childhood education and care. In L. Gambaro, K. Stewart, \& J. Waldfogel (Eds.), CASE studies on poverty, place and policy: An equal start? Providing quality early education and care for disadvantaged children (pp. 147-170). Bristol, UK: Policy Press.

Minister of Education. (2011). Continuing support for Playcentre. Retrieved from https://www.beehive.govt.nz/release/continuing-support-playcentre

Minister of Education. (2018). Education funding review: Proposed new direction (Cabinet paper). Retrieved from http://www.education.govt.nz/ministry-of-education/ consultations-and-reviews/recent-consultations-and-reviews/education-fundingsystem-review/

Ministry of Education. (1990). Early childhood education qualifications and training: $A$ blueprint for the future. Wellington, NZ: Author.

Ministry of Education. (1996). Te Whāriki: Early childhood curriculum: He whāriki mātauranga mō ngā mokopuna o Aotearoa. Wellington, NZ: Learning Media.

Ministry of Education. (2002). Pathways to the future/Ngā huarahi arataki: A 10 year strategic plan for early childhood education. Wellington, NZ: Author.

Ministry of Education. (2012). Sector Advisory Group reports. Retrieved from https://assets.documentcloud.org/documents/1994969/ece-sector-advisory.pdf

Ministry of Education. (2016a). Cabinet paper review of funding systems: Update and next steps. Retrieved from http://www.education.govt.nz/ministry-ofeducation/consultations-and-reviews/education-funding-systemreview/background-information-for-the-education-funding-system-review/

Ministry of Education. (2016b). Teacher-Led Innovation Fund guide: ECE version. Retrieved from http://www.education.govt.nz/ministry-of-education/specificinitiatives/investing-in-educational-success/teacher-led-innovationfund/information-to-help-your-application/\#ece

Ministry of Education. (2017a). Te Whāriki: He whāriki mātauranga mō ngā mokopuna o Aotearoa/Early childhood curriculum. Retrieved from https://education.govt.nz/early-childhood/teaching-and-learning/ece-curriculum/tewhariki/.

Ministry of Education. (2017b). Update of Te Whāriki: Report on the engagement process. Retrieved from http://tewhariki.tki.org.nz/en/the-story-of-te-whariki/

Mitchell, L., Royal Tangaere, A., Mara, D., \& Wylie, C. (2006). Quality in parent/whānau-led services: Summary research report. Wellington, NZ: Ministry of Education.

OECD. (2012). Quality matters in early childhood education and care: New Zealand 2012. Paris: Author.

Playcentre Journal Editor. (1990) Editor's note. Playcentre Journal, 79, 31.

Podmore, V. N., \& Te One, S. (2008). Nurturing a culture of care for infants and first-time parents: The SPACE programme at Te Marua/Mangaroa Playcentre early childhood centre of innovation (Round Two). Retrieved from http://thehub.superu.govt.nz/publication/coi-te-maruamangaroa-playcentre-spaceprogramme-nurturing-culture-care-infants-and-first

Powell, K., Cullen, J., Adams, P., Duncan, J., \& Marshall, K. (2005). The effect of adult Playcentre participation on the creation of social capital in local communities: Report to the New Zealand Playcentre Federation. Palmerston North, NZ: Massey University \& NZPF. 
Smith, A., \& May, H. (2018). Connections between early childhood policy and research in Aotearoa New Zealand: 1970s-2010s. In M. Fleer \& B. van Oers (Eds.), International handbook of early childhood education (pp. 531-549). Dordrecht, The Netherlands: Springer.

Stover, S. (1998). The debate continues: Adult education in Playcentre. In S. Stover (Ed.), Good clean fun: New Zealand's Playcentre movement (pp. 47-62). Auckland, NZ: Playcentre.

Stover, S. (2001). Planning for Playcentres: A hands-on resource. Auckland, NZ: Playcentre.

Stuart, M. (2016). Out of place: Economic imperialisms in early childhood education. Educational Philosophy and Theory, 48(2), 138-149. doi:10.1080/00131857.2014.971094

Teaching and Learning Research Initiative (TLRI). (n.d.). Teaching and Learning Research Initiative (TLRI). Retrieved from http://www.tlri.org.nz/

van Wijk, N., Simmonds, A., Cubey, P., Mitchell, L., Bulman, R., Wilson, M., \& Wilton Playcentre members. (2006). Transforming learning at Wilton Playcentre. Retrieved from https://www.educationcounts.govt.nz/publications/ECE/22551/34856

van Wijk, N., \& Wilton Playcentre members. (2007). Wilton Playcentre: A community of learners, tall and short. In A. Meade (Ed.), Cresting the waves: Innovation in early childhood education (pp. 56-62). Wellington, NZ: NZCER Press.

Waitangi Tribunal. (2012). Matua Rautia: Report on the Kōhanga Reo claim, Wai 2335. Retrieved from http://www.justice.govt.nz/tribunals/waitangi-tribunal/Reports/wai2336-the-kohanga-reo-claim

Wannan, O., \& Livingston, T. (2015, October 14). Capital kindergartens may lose teachers to cuts. Stuff. Retrieved from http://www.stuff.co.nz/national/education/73012392/Capital-kindergartens-maylose-teachers-to-cuts

Suzanne Manning has recently completed a PhD through the University of Auckland, which examined the impact of early childhood policy on Playcentres, a parent cooperative service unique to Aotearoa New Zealand, from the late 1980s. Her research interests combine the disciplines of history, policy and education, fitted around work as a learning advisor at Whitireia NZ. 